JURNAL PENDIDIKAN, p-ISSN 2715-095X, e-ISSN 2686-5041

Volume 30, No.2, Juli 2021 (153-164)

Online: http://journal.univetbantara.ac.id/index.php/jp

\title{
Pemanfaatan Laman Web Make Beliefs Comix dalam Pembuatan Media Pembelajaran Bahasa Indonesia Berbasis Komik Digital
}

\author{
Jesyischa Rizky Devista dan Tito Tri Kadafi* \\ UIN Syarif Hidayatullah Jakarta, E-mail: jesika.devista18@mhs.uinjkt.ac.id, tri.tito18@mhs.uinjkt.ac.id
} *Corresponding Author

Received: May 21, $2021 \quad$ Accepted: Juni 07, 2021 Online Published: Juni 26, 2021

\begin{abstract}
Abstrak: Penelitian ini betujuan untuk mengembangkan dan memunculkan inovasi dalam penciptaan media pembelajaran berbasis digital, terutama komik digital dalam pembelajaran bahasa Indonesia. Peneliti menggunakan metode kualitatif, memanfaatkan data yang diperoleh dari 60 orang responden yang menjadii informan dalam penelitian ini dengan mengisi angket yang disebarkan melalui Google Formulir. Teknik analisis datanya dengan menganalisis jawaban angket dan memetakannya menjadi data penelitian. Hasil penelitian ini adalah media komik digital sangat menarik untuk dikembangkan menjadi media pembelajaran, terlebih dengan memanfaatkan laman Make Beliefs Comix yang memiliki banyak kelebihan, yakni laman Make Beliefs Comix dapat digunakan tanpa harus mengunduk aplikasi, dapat digunakan oleh pengguna yang tidak terampil dalam menggambar, mudah dalam pengoperasiannya, dan hemat biaya. Sedangkan kekurangan laman ini yakni, memerlukan koneksi intenet yang baik serta memerlukan komputer jinjing atau komputer agar lebih mudah digunakan.
\end{abstract}

Kata-kata Kunci: Make Beliefs Comix, Media Pembelajaran, dan Teknologi

\section{Utilization of Make Beliefs Comix Webpage to Making Indonesian Language Learning Media Based on Digital Comics}

\author{
Jesyischa Rizky Devista and Tito Tri Kadafi
}

UIN Syarif Hidayatullah Jakarta,E-mail: jesika.devista18@mhs.uinjkt.ac.id, tri.tito18@mhs.uinjkt.ac.id

\begin{abstract}
This study aims to develop and create innovations in the creation of digital-based learning media, especially digital comics in Indonesian language learning. Researchers used qualitative methods, with utilizing data obtained from 60 respondents who became informants in this study by filling out questionnaires distributed through Google Forms. The data analysis technique is by analyzing the questionnaire answers and mapping them into research data. The results of this study are that digital comics media are very interesting to be developed into learning media, especially by utilizing the Make Beliefs Comix page which has many advantages, namely the Make Beliefs Comix page can be used without having to download the application, can be used by users who are not skilled in drawing, easy to use in operation, and cost-effective. While the disadvantages of this page are that it requires a good internet connection and requires a laptop or computer to make it easier to use.
\end{abstract}

Keywords: Make Beliefs Comix, Learning Media, and Technology

\section{Pendahuluan}

Dewasa ini, masyarakat dihadapkan dengan perkembangan teknologi yang semakin pesat. Banyaknya jumlah penduduk Indonesia membuat konsumsi internet sebagai jendela baru mengalirnya beragam informasi turut meningkat. Dikutip dari data Badan Pusat 
Statistik, pada 2019 penduduk Indonesia berjumlah 268 juta jiwa. Dengan jumlah penduduk yang banyak, disertai pula dengan kemajuan teknologi, membuat masyarakat agaknya dewasa ini tidak bisa lepas seutuhnya dari jeratan gawai dan internet. Dikutip dari data Kementerian Komunikasi dan Informatika Republik Indonesia, pada 2019 pengguna internet di Indonesia mencapai 150 juta jiwa, dengan penetrasi 56\% yang tersebar di seluruh wilayah Indonesia. Setahun berselang, dengan kondisi yang mengharuskan masyarakat untuk bekerja serta belajar dari rumah akibat pandemi Covid-19, tentu berakibat pula pada meningkatnya angka penggunaan internet. Dikutip dari data Kementerian Komunikasi dan Informatika Republik Indonesia, pada April 2020, pengguna internet di Indonesia meningkat hingga 40\%. Peningkatan yang dapat dikatakan signifikan tentunya. Jumlah pengguna internet yang tinggi ini membuktikan bahwa masyarakat Indonesia sudah dapat mengikuti pola perkembangan zaman atau era digitalisasi dengan baik. Banyak bidang yang sudah beralih haluan dari yang tadinya dilakukan secara langsung, namun saat ini sudah diadaptasi menjadi serba daring, salah satunya dari sektor pendidikan (Suwarto, 2017). Semakin berkembangnya teknologi menghadirkan banyak kemudahan dan melahirkan banyak inovasi-inovasi dalam berbagai aspek kehidupan, terlebih dalam dunia pendidikan beserta segala hal yang terkandung di dalamnya. Era kemajuan teknologi membuat guru dituntut untuk bersiap dan dapat menghadirkan banyak kreasi pembelajaran menyenangkan, dan tentu saja direalisasikan salah satunya melalui penciptaan berbagai media pembelajaran yang kreatif, inovatif, serta menyenangkan bagi peserta didik untuk menunjang keberhasilan proses pembelajaran yang dilakukan di kelas. Dari sektor pendidikan, perkembangan teknologi harus dimanfaatkan dengan baik oleh tiap-tiap tenaga pendidik, salah satunya dalam menghadirkan serta mengembangkan media pembelajaran yang akan digunakan dalam menyampaikan materi pembelajaran di kelas. Media berasal dari bahasa Latin dan merupakan bentuk jamak dari kata medium, yang artinya pengantar. Maka dapat dikatakan bahwa, media merupakan sebuah wahana penyalur informasi atau pesan saat proses pembelajaran (Djamarah \& Zain, 2010: 120).

Media pembelajaran adalah segala bentuk alat komunikasi yang dapat digunakan untuk menyampaikan informasi dari sumber (baik guru maupun buku-buku teks) ke peserta didik secara terencana, sehingga tercipta lingkungan belajar yang kondusif, dimana penerimanya dapat melakukan proses pembelajaran secara efisien dan efektif (Hamzah \& Lamatenggo, 2011: 122). Daryanto dalam Kanti menyatakan bahwa media pembelajaran dapat dikatakan efektif apabila dapat meningkatkan pencapaian tujuan pembelajaran, tingkat pencapaian tujuan tersebut berupa peningkatan pengetahuan dan keterampilan serta pengembangan sikap melalui proses pembelajaran (Kanti, dkk, 2018:135). Agar media pembelajara ini menjadi sebuah media pembelajaran yang efektif, tentu saja harus dirancang dan dikreasikan semenarik mungkin oleh tenaga pendidik. Butuh eksplorasi dan uji coba terhadap media yang digunakan supaya materi pembelajaran tersampaikan dengan baik. Burhanudin dalam Kadafi menyatakan bahwa media media alat yang dipakai sebagai saluran untuk menyampaikan suatu pesan atau informasi dari sumber kepada penerimanya (Kadafi, 2021: 24). Sebuah media pembelajaran, dapat dikategorikan atau disebut menarik apabila menimbukan keingintahuan lebih lanjut dan rasa penasaran, sehingga muncul dorongan dalam diri peserta didik untuk lebih aktif dan mandiri (Rusman, 2013: 173). Keaktifan peserta didik di kelas sedikit banyaknya dipengaruhi oleh media pembelajaran. Terdapat kemungkinan rendahnya kemampuan belajar siswa dapat disebabkan karena media pembelajaran yang digunakan oleh guru kurang dapat mengaktifkan siswa (Pambudi, $\mathrm{dkk}, 2019$ : 176). Media pembelajaran yang dapat mengaktifkan siswa ini merupakan 
sebuah media pembelajaran yang menarik. Media pembelajaran yang menarik dapat diciptakan, dikreasikan serta dikembangkan sesuai dengan kemampuan-kemampuan yang dimiliki oleh tenaga pendidik, salah satunya dengan memanfaatkan media pembelajaran berbasis teknologi, serta memanfaatkan perkembangan teknologi pada masa ini. Pemilihan media pembelajaran juga berperan penting dalam proses pembelajaran, terlebih pada pembelajaran jarak jauh; sesuai konteks saat penelitian ini ditulis. Mengutip hasil penelitian Adriani dkk, diketahui banyak sekali dampak yang diperoleh baik teknis maupun guru mengetahui bahwa siswa kurang puas, siswa kurang puas dengan metode PJJ yang mereka gunakan saat ini, dan guru juga kurang puas dengan kemampuan guru menyampaikan materi ke siswa (Adriani, dkk, 2021: 53). Ketidakpuasan ini yang menjadi dasar pentingnya pemilihan media pembelajaran.

Media pembelajaran hadir dengan berbagai jenis, di antaranya adalah media visual, audio, ataupun audio visual. Media visual umumnya menjadi sebuah media pembelajaran yang paling banyak dan kerap digunakan di mana-mana. Ada bermacam-macam media visual, diantaranya gambar, sketsa, diagram, poster, grafik, buku, komik, flip chart, dan lain-lain (Rusman, 2009: 166). Beberapa media visual tersebut mungkin sudah sering digunakan, terlebih dalam pembelajaran bahasa Indonesia. Namun, terdapat satu media visual yang belum ramai digunakan saat pembelajaran bahasa Indonesia, dan penggunaan media ini dapat memanfaatkan perkembangan teknologi yang kini sedang mengiringi masing-masing penduduk Indonesia. Salah satu media pembelajaran visual berbasis teknologi yang dapat diadaptasi oleh tenaga pendidik adalah komik digital. Mengutip penelitian yang dilakukan oleh Styaningsih, dkk, komik digital memuat pesan berupa gambar-gambar diam dan tulisan yang membentuk rangkaian cerita dan mampu memberikan gambaran lebih nyata sehingga dapat menarik perhatian serta minat siswa untuk belajar (Styaningsih, dkk, 2016: 131). Komik digital akan meningkatkan ketertarikan peserta didik dalam memperhatikan pemaparan materi dari tenaga pendidik, sebab nuansa yang penuh ceria serta objek-objek atau karakter dalam komik yang banyak akan membuat peserta didik tertarik. Visualisasi komik digital yang baik ini tentu sedikit banyaknya akan berdampak pada keberhasilan peserta didik dalam menyerap materi pembelajaran. Berdasarkan kerucut pengalaman Edgar Dale, peserta didik akan mengingat sebanyak 30\% berdasarkan apa yang mereka lihat, dan dalam implementasinya media komik ini akan disertai pula dengan pemaparan materi berupa audio dari tenaga pendidik, yang akan meningkatkan kemampuan mengingat peserta didik menjadi $50 \%$, berdasarkan apa yang mereka lihat dan dengar.

Joko dalam Wahyuni mengungkapkan bahwa gaya belajar merupakan suatu proses gerak laku, penghayatan, serta kecenderungan seorang pelajar mempelajari ataupun memperoleh suatu ilmu dengan cara yang tersendiri (Wahyuni, 2017: 128). Ada beragam jenis gaya belajar, di antaranya gaya belajar visual, auditori, dan kinestetik. Gaya belajar belajar peserta didik yang beragam ini sepertinya tidak terlalu menjadi persoalan dengan pemanfaatan media pembelajaran komik digital. Sebab, media komik digital ini cocok digunakan untuk memberikan materi kepada siswa yang memiliki gaya belajar visual dan gaya belajar auditori. Gaya belajar visual adalah saat peserta didik menitikberatkan pada penglihatan (Kadaruddin, 2016: 144). Hal ini sejalan dengan pemanfaatan media komik, yang memberikan kesan visualisasi menarik kepada peserta didik, berupa teks serta gambar. Sehingga, tentunya media komik digital ini cocok untuk peserta didik yang memiliki gaya belajar visual. Sedangkan, gaya belajar auditori adalah saat peserta didik menitikberatkan pada pendengaran (Kadaruddin, 2016: 147). Gaya belajar auditori ini juga dapat diatasi 
dengan media komik digital, sebab tentunya tenaga pendidik akan memaparkan materi tersebut di depan kelas, dan hal ini amat memudahkan peserta didik yang menggunakan gaya belajar auditori. Sehingga, peneliti menganggap media pembelajaran komik digital ini amat menarik untuk dikembangkan dan diamati lebih lanjut keunggulan serta kelemahannya. Kemenarikan komik ini untuk dijadikan media pembelajaran tidak sejalan dengan realita sosial yang sama-sama kita saksikan dewasa ini. Sebab, dengan berbagai kendala yang dimiliki, misalnya seorang guru tidak pandai menggambar, serta kemampuan guru dalam menciptakan sebuah visualisasi berupa karakter yang kurang, kerap menjadi alasan mengapa tidak banyak guru-guru bahasa Indonesia yang menggunakan media komik sebagai alat bantu penyampaian materi di kelas. Padahal, komik bisa menjadi sebuah solusi tatkala siswa jenuh dengan suasana pembelajaran yang berlangsung di kelas.

Saat ini, terdapat banyak aplikasi dan laman yang dapat memudahkan seorang guru saat membuat media pembelajaran berbasis komik, salah satunya yakni laman Make Beliefs Comix. Laman Make Beliefs Comix ini dapat didapatkan saat pembaca berselancar melalui peramban, dan dapat diakses tanpa perlu mengunduh aplikasi. Selain itu, di saat aplikasi lain tetap memerlukan kemampuan menggambar untuk meciptakan sebuah komik, Make Beliefs Comix hadir dengan fitur-fitur sederhana yang tentunya dapat dioperasikan oleh siapa saja yang mengakses laman Make Beliefs Comix tersebut, sebab pengoperasian laman pembuat komik digital yang amat sederhana dan mudah ini. Namun, dewasa ini, masih belum banyak ada tenaga pendidik yang mengetahui perihal laman Make Beliefs Comix, selaku laman pembuatan komik yang lebih sederhana dan tidak rumit tersebut. Belum banyaknya tenaga pendidik yang mengetahui hal ini, didasari karena berbagai hal, diantaranya adalah karena belum banyaknya tulisan perihal pembuatan media pembelajaran melalui laman Make Beliefs Comix ini. Berdasarkan penelusuran sementara penulis di peramban, penulis belum menemukan ada sebuah tulisan yang membahas secara rinci perihal pemanfaatan laman Make Beliefs Comix untuk pembuatan media pembelajaran, khususnya pembelajaran bahasa Indonesia.

Pembelajaran bahasa Indonesia umumnya menampilkan narasi yang panjang, yang juga menjadi stigma di kalangan peserta didik. Hal ini menjadikan pembelajaran bahasa Indonesia dipandang membosankan. Pendidik perlu mengeksplorasi penggunaan media lebih baik, dengan memetakan kebutuhan konteks materi yang diajarkan. Misalnya, pada pembelajaran fakta dan opini, pendidik tidak hanya semata-semata cukup menjabarkan pengertian panjang soal fakta dan opini, namun juga perlu memerhatikan pemahaman peserta didik, yang nantinya akan berimplikasi pada hasil belajar. Penggunaan media komik adalah salah satu jalan yang dapat ditempuh pendidik, termasuk dengan memanfaatkan media Make Beliefs Comix. Salah satu penelitian yang telah membahas perihal penggunaan media komik yakni penelitian dari Andi Wardana, dalam penyelesaian skripsinya yang berjudul Pengembangan Komik sebagai Media Pembelajaran untuk Mengapresiasi Cerita Anak pada Peserta Didik Kelas III SD/MI. Namun, dalam penelitian tersebut, pembuatan komik dilakukan dengan memanfaatkan software Corel Draw X4. Sehingga, cukup sulit untuk menghasilkan media, karena harus membuat pola gambar, pewarnaan, serta pemberian teks dialog (Wardana, 2018: 66). Sehingga, meskipun ada banyak tulisan terkait pemanfaatan media komik digital sebagai media pembelajaran, belum ada tulisan yang secara spesifik membahas pembuatan komik digital dengan memanfaatkan laman Make Beliefs Comix. Berdasarkan beberapa alasan yang penulis jabarkan tersebut, di antaranya penggunaan yang cukup mudah terlebih untuk pemula, serta belum terlalu banyak masyarakat umum yang mengetahui laman pembuat komik digital ini, kemudian membuat 
penulis tertarik untuk menjadikan laman ini sebagai penelitian yang selanjutnya dipublikasikan ke media. Penelitian mengenai laman Make Beliefs Comix ini dilakukan agar dapat mengembangkan dan memunculkan inovasi baru dalam pengadaan media pembelajaran bahasa Indonesia berbasis digital, sehingga akan semakin banyak guru yang dapat memanfaatkan laman ini untuk membuat media pembelajaran yang kreatif, inovatif, serta menyenangkan bagi peserta didik, terutama pada pembelajaran bahasa Indonesia.

\section{Metode Penelitian}

Penelitian ini menggunakan metode deskriptif kualitatif, dengan mengumpulkan tanggapan-tanggapan terkait media pembelajaran komik digital yang telah penulis buat. Penelitian kualitatif merupakan penelitian yang menghasilkan dan mengolah data yang sifatnya deskriptif, seperti transkripsi wawancara, catatan lapangan, gambar, foto, rekaman video, dan lain-lain (Poerwandari, 1998: 38). Data yang digunakan dalam penelitian ini, peneliti himpun melalui angket, berupa survei yang disebarluaskan melalui google formulir. Responden yang mengisi angket dalam google formulir ini sejumlah 60 responden terkait. Terdapat beberapa pertanyaan dalam formulir daring yang disebarkan, di antaranya pertanyaan terkait media apa yang biasanya paling sering digunakan oleh guru di kelas, apakah guru pernah menggunakan media pembelajaran berupa komik digital, pandangan mereka tentang penggunaan media komik digital dalam pembelajaran di kelas, serta berapa nilai yang mereka berikan atas penggunaan komik ini dalam pembelajaran (skala 10-100). Peneliti menganalisis data ini dengan melihat persentase dari jawaban-jawaban responden, sebagai acuan untuk menentukan hasil penelitian. Jawaban responden atas pertanyaan terkait tanggapan dianalisis dengan mengambil sampel deskripsi tanggapan yang peneliti anggap merepresentasikan hasil.

\section{Hasil Penelitian}

Data dalam penelitian ini peneliti ambil berdasarkan tanggapan pelajar tentang media pembelajaran komik digital yang telah penulis buat sebelumnya. Tanggapan tersebut peneliti himpun melalui data tanggapan-tanggapan responden yang mengisi survei melalui google formulir yang telah peneliti buat sebelumnya. Google formulir tersebut ditanggapi oleh 60 responden dengan asal sekolah yang berbeda-beda.

\section{Pandangan Terhadap Media Pembelajaran Komik Digital}

Media pembelajaran berbasis komik digital ini terbilang amat menjanjikan untuk dikembangkan, sebab belum terlalu banyak guru bahasa Indonesia yang menggunakan media pembelajaran dengan memanfaatkan perkembangan teknologi. Hal ini dibuktikan dengan tanggapan responden, yakni sebanyak $85 \%$ responden atau 51 orang menyatakan guru pengampu mata pelajaran bahasa Indonesia di sekolah responden tersebut, tidak pernah menggunakan media pembelajaran berupa komik digital saat mengajar di kelas. Sedangkan hanya sebanyak $15 \%$ responden atau 9 orang menyatakan guru pengampu mata pelajaran bahasa Indonesia di sekolah responden tersebut, pernah menggunakan media pembelajaran berupa komik digital saat mengajar di kelas. Persentase tersebut membuktikan bahwa media pembelajaran komik digital ini memiliki peluang untuk digunakan serta disebarluaskan informasi perihal cara pembuatannya, agar lebih banyak tenaga pendidik di Indonesia yang di kemudian hari akan memanfaatkan media komik digital dalam pembelajaran di kelas. Tidak banyaknya tenaga pendidik yang menggunakan media pembelajaran komik digital ini dikarenakan berbagai hal, di antaranya adalah kurangnya informasi serta pemahaman terkait aplikasi yang dapat digunakan untuk memudahkan tenaga pendidik dalam proses pembuatan komik digital tersebut. Sebab, 
stigma banyak orang masih beranggapan bahwa membuat sebuah komik tentu mengharuskan orang yang akan membuat ini pandai menggambar, agar menghasilkan visualisasi komik yang menarik.

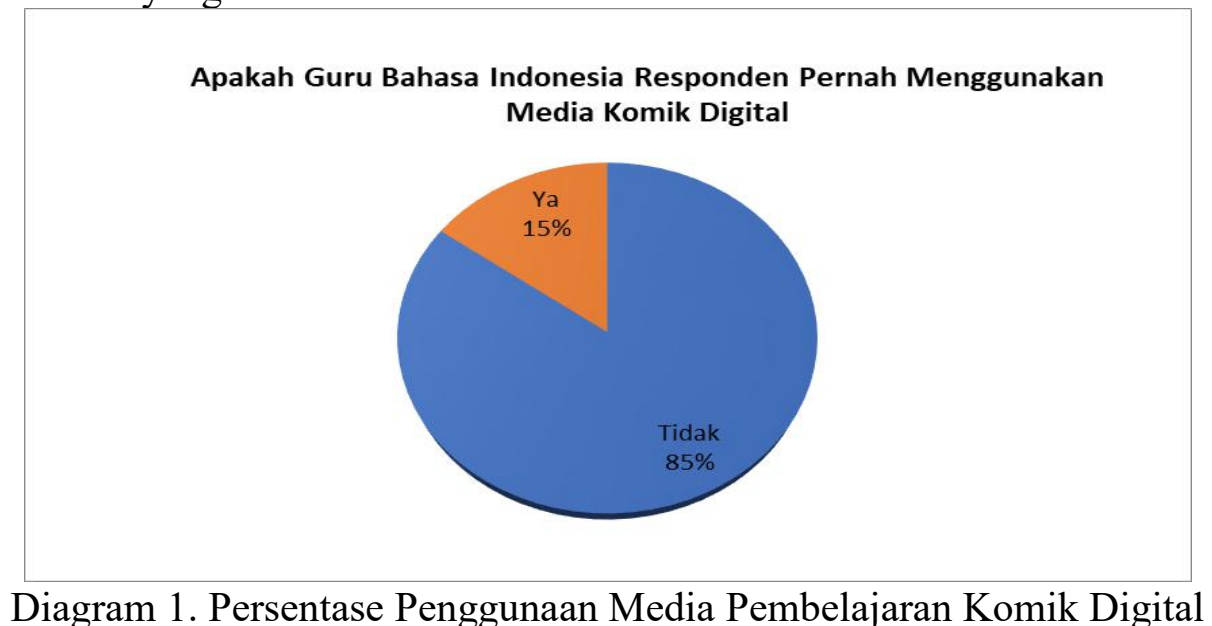

Padahal, telah ada beberapa aplikasi atau laman khusus seperti laman Make Beliefs Comix yang akan memudahkan tenaga pendidik dalam membuat media pembelajaran komik digital yang amat menarik. Sehingga, berdasarkan beberapa poin tersebut, peneliti beranggapan bahwa peluang untuk menciptakan media pembelajaran yang menarik dengan memanfaatkan perkembangan teknologi informasi, belum sepenuhnya dimanfaatkan dengan baik oleh tenaga pendidik untuk menunjang efektivitas proses pembelajaran di kelas.

Setelah peneliti melakukan survey dengan menguji apakah media pembelajaran yang peneliti buat, yakni komik digital tersebut menarik atau tidak menurut peserta didik jika diterapkan saat pembelajaran bahasa Indonesia di kelas, sebanyak 58 responden, atau sebesar 96,67\% dari responden menyatakan bahwa media pembelajaran komik digital tersebut menarik, sedangkan hanya ada sebanyak 2 responden atau sebesar 3,33\% dari responden yang menyatakan bahwa media pembelajaran komik digital tersebut kurang menarik. Persentase tersebut membuktikan bahwa komik digital yang penulis lampirkan dalam google formulir tersebut dinilai amat menarik bagi responden. Hanya ada dua responden yang menyatakan bahwa media pembelajaran berbasis komik tersebut kurang menarik jika diterapkan dalam pembelajaran di kelas. Hal-hal yang menjadi alasan penyebab responden menyatakan media pembelajaran berbasis komik digital yang peneliti lampirkan dalam google formulir tersebut sebagai sebuah media pembelajaran yang kurang menarik, yakni "Tidak menarik karena begitu banyak tulisan, sehingga space-nya terlalu padat", dan "akan susah dimengerti".

Alasan pertama mungkin hadir karena potongan komik yang peneliti hadirkan dalam google formulir terlalu rapat, sebab memiliki enam bilah kotak atau enam buah kanvas dalam satu bingkai komik tersebut. Sedangkan alasan kedua yang diberikan oleh responden lainnya, mungkin hadir karena bisa jadi bahan materi dalam komik yang peneliti hadirkan tidak terlalu menarik, rapi, dan terorganisir, sehingga masih terdapat satu orang responden yang tidak dapat memahami dengan baik apa saja sebetulnya substansi-substansi materi yang disuguhkan dalam komik tersebut. Namun, yang menarik perhatian peneliti adalah ada sebanyak 58 responden yang menyatakan bahwa media pembelajaran komik digital 
tersebut menarik. Hal ini tentu dilatarbelakangi oleh berbagai hal yang menarik perhatian responden.

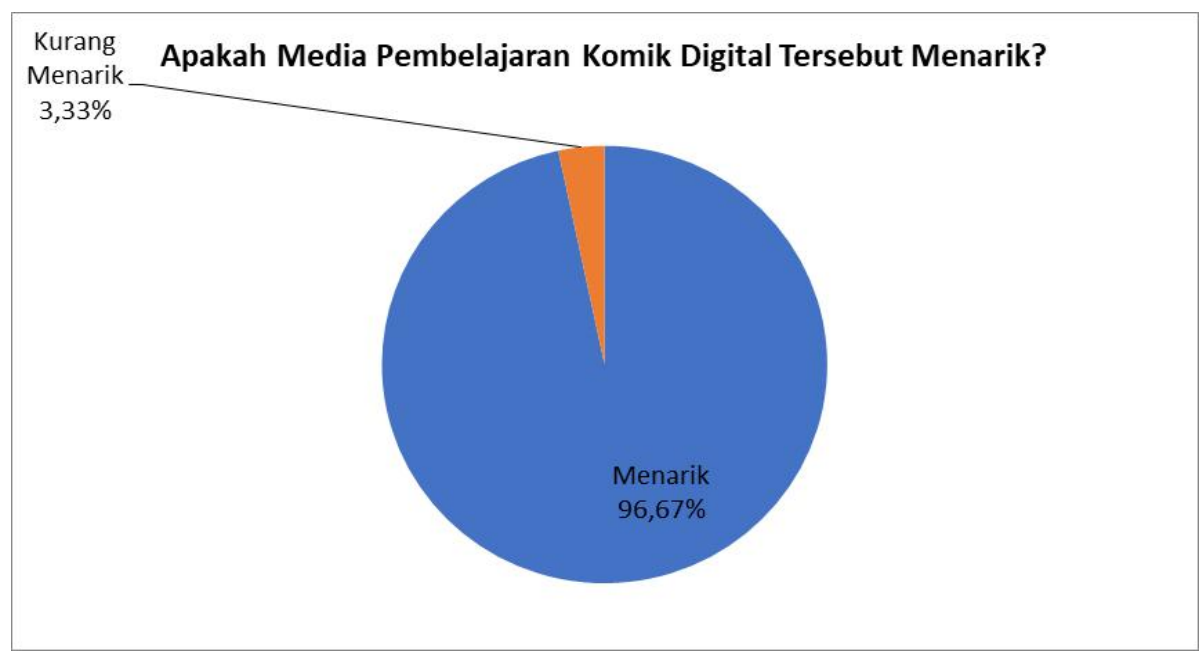

Diagram 2. Persentase Menarik atau Tidaknya Media Komik yang Peneliti Contohkan

Beberapa tanggapan responden yang menyatakan media komik digital tersebut menarik, disertai alasan-alasan berikut: (1). Media komik tersebut memberikan kesan yang sangat tidak membosankan, karena tidak monoton dengan hanya berisi teks atau tulisan saja, tetapi juga terdapat gambar-gambar lucu yang menarik. (2). Media komik tersebut menarik karena selain tulisan, siswa juga disuguhkan dengan gambar yang mendukung, serta warnawarna yang memungkinkan dapat meningkatkan ketertarikan siswa untuk membaca. Ilustrasi dalam komik juga mungkin akan dapat mendukung pemahaman dari pesan yang hendak disampaikan melalui komik tersebut.Apalagi, di era digital seperti saat ini, mengakses komik digital sudah sangat mudah. (3). Menarik karena jarang sekali guru menggunakan media gambar komik dan saya pribadi menyukai komik.(4). Cukup menarik, karena komik digital ini merupakan media pembelajaran yang cukup jarang digunakan, dan dengan komik digital tersebut, siswa akan lebih tertarik untuk mengikuti mata pelajaran bahasa Indonesia, yang biasanya terkesan sebagai mata pelajaran yang banyak sekali teksnya. Oleh sebab itu, dengan didukung gambar-gambar pada komik digital tersebut, siswa akan mengikuti pembelajaran dengan euforia yang lebih menyenangkan. (5). Menarik, karena sesekali siswa harus diberikan gambaran nyata, agar persepsinya sama dengan yang dimaksud oleh tenaga pendidik. (6). Terlihat lebih beda dengan media pembelajaran lainnya, sehingga tentu saja lebih menarik. Sebab, media pembelajaran seperti komik digital ini jarang digunakan oleh banyak orang. Adanya gambar-gambar akan membuat suasana pembelajaran terlihat tidak monoton. (7). Media komik digital ini dapat dibilang menarik, karena penggunaan analogi dan penggambaran cerita dalam kehidupan sehari-hari dapat membantu siswa untuk memahami suatu materi dengan mudah dan menyenangkan. (8). Komik digital atau komik dalam bentuk buku tetap menarik. Karena dapat membuat materi atau pelajaran menjadi tidak monoton. Namun, terkadang ada yang membedakan antara komik digitl dengan komik dalam bentuk buku, biasanya komik digital lebih berwarna, sehingga lebih menarik perhatian. Serta, tentu saja bagi murid yang memang menyukai komik akan senang jika pelajarannya menggunakan media seperti ini. (9). Media komik digital ini jarang digunakan, dan memiliki peluang untuk lebih mudah mengantarkan 
pesan kepada peserta didik. (10). Menarik, karena mengurangi rasa bosan. Terkadang saat belajar bahasa Indonesia, gurunya terlalu monoton. Dari 58 responden yang menyatakan media komik digital ini menarik, peneliti hanya menyantumkan 10 alasan, sebagaimana yang terlampir di atas. Hal ini disebabkan karena alasan-alasan yang dikemukakan oleh responden-responden lainnya secara garis besar sama dengan yang peneliti cantumkan dalam artikel ini, yakni menarik karena akan membuat suasana belajar menyenangkan dan tidak membosankan, adanya banyak warna membuat peserta didik lebih bersemangat mengikuti pembelajaran, media ini masih jarang digunakan sehingga akan menarik jika diimplementasikan dalam proses belajar mengajar di kelas, dan karena komik ini menghadirkan ilustrasi nyata, maka peserta didik akan lebih mudah memahami materi pembelajaran yang disampaikan melalui media tersebut.
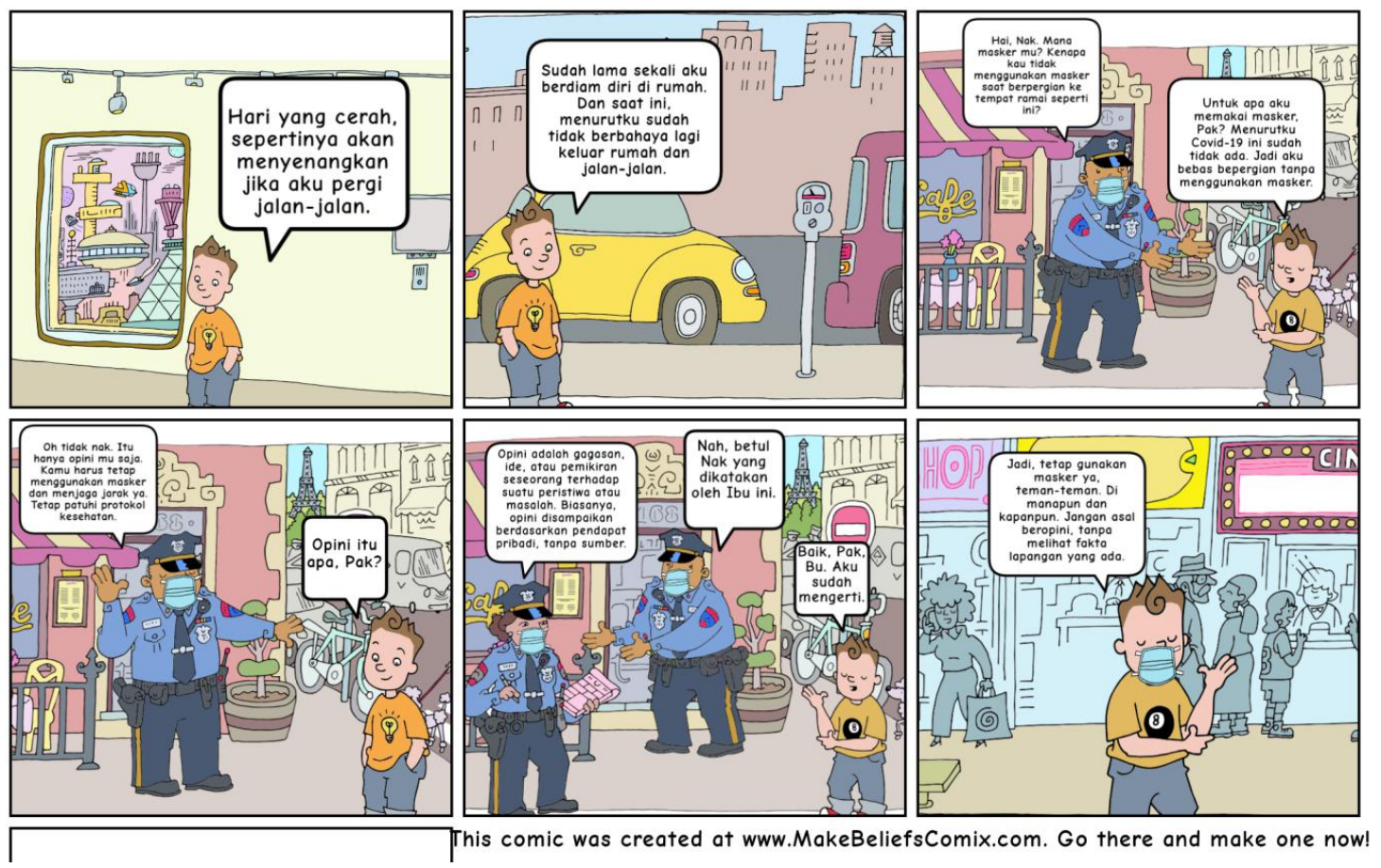

Gambar 1. Komik Digital yang Penulis Cantumkan dalam Google Formulir

Selain menyatakan pandangan mereka terhadap media pembelajaran komik tersebut, responden juga memberikan nilai atas media pembelajaran tersebut apabila digunakan dalam pembelajaran bahasa Indonesia di kelas. Berdasarkan penilaian tersebut, hasilnya ialah 1 orang responden atau sebesar $1,7 \%$ responden memberikan nilai 30.1 orang responden atau sebesar $1,7 \%$ responden memberikan nilai 50. 2 orang responden atau sebesar 3,3\% responden memberikan nilai 60.3 orang responden atau sebesar 5,0\% responden memberikan nilai 70. 23 orang responden atau sebesar 38,3\% responden memberikan nilai 80.19 orang responden atau sebesar 31,7\% responden memberikan nilai 90, dan 11 orang responden atau sebesar 18,3\% responden memberikan nilai 100 . Berdasarkan data nilai tersebut, maka dapat disimpulkan pula ada sebanyak 7 orang responden memberikan nilai kurang dari atau sama dengan 70, dan ada 53 orang responden yang memberikan nilai lebih dari atau sama dengan 80 untuk media pembelajaran berbasis komik digital tersebut. 


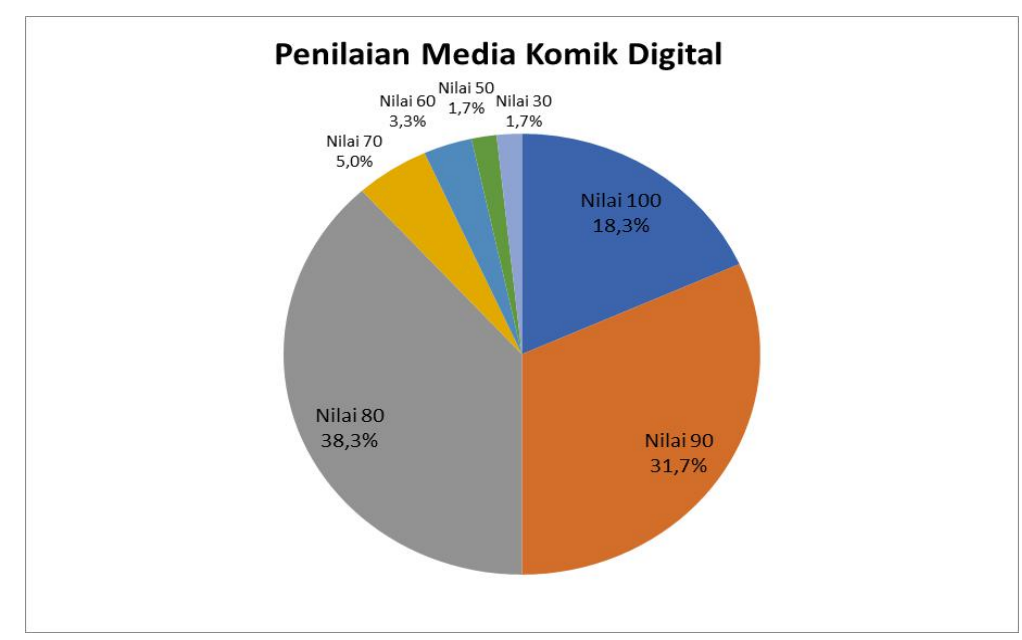

Diagram 3. Penilaian Responden Terhadap Media Pembelajaran Komik Digital

\section{Pembahasan}

\section{Kekurangan dan Kelebihan Laman Make Beliefs Comix}

Selain memaparkan terkait tanggapan-tanggapan responden mengenai penggunaan media pembelajarans komik digital yang penulis buat, penulis juga merasa perlu untuk memaparkan apa saja kelebihan dan kekurangan laman Make Beliefs Comix jika dimanfaatkan sebagai laman pembuat komik digital. Sebab, pembaca secara umum tentu memerlukan acuan agar dapat mempertimbangkan lebih lanjut pemanfaatan lama Make Beliefs Comix ini.

\section{Kekurangan}

Kekurangan laman Make Beliefs Comix dalam pembuatan media pembelajaran komik digital tersebut, yakni: (1). Akan lebih baik jika diakses menggunakan komputer atau laptop. Menurut peneliti, ini akan menjadi salah satu kekurangan dari pembuatan media pembelajaran berbasis komik melalui laman Make Beliefs Comix. Jadi, tenaga pendidik yang hendak berkreasi dengan media pembelajaran, harus memiliki laptop ataupun komputer, agar dapat dengan mudah memanfaatkan tiap fitur yang disediakan di laman Make Beliefs Comix ini. Apabila tenaga pendidik tidak memiliki komputer maupun laptop dan hendak membuat media pembelajaran komik melalui laman Make Beliefs Comix dengan menggunakan gawai, maka akan sedikit sulit dalam mengkreasikan dan mengoperasikan fitur-fitur yang tersedia. Layar gawai jika dibandingkan dengan layar komputer ataupun laptop sudah pasti berbeda ukurannya. Layar gawai yang lebih kecil tentu akan membuat ruang gerak dalam mengkreasikan tiap fitur terbatas, berbeda dengan apabila tenaga pendidik menggunakan laptop atau komputer dalam pembuatan komik digital tersebut. (2). Memerlukan koneksi internet yang baik, sebab laman Make Beliefs Comix tidak bisa diakses tanpa koneksi internet. Menurut peneliti, ini akan menjadi kekurangan dari laman Make Beliefs Comix, sebab laman ini tidak mengharuskan pengguna untuk mengunduh aplikasi, sehingga pengguna hanya dapat memanfaatkan fitur-fiturnya dengan koneksi internet. Apabila tenaga pendidik yang akan memanfaatkan laman Make Beliefs Comix ini berada di lokasi yang minim koneksi internet, maka akan membuat tenaga pendidik tersebut kesulitan membuat komik digital menggunakaan laman ini. (3). Akan sedikit membingungkan jika pengguna tidak paham bahasa Inggris. Peneliti menyadari mungkin saja pengguna laman Make Beliefs Comix tersebut tidak semuanya paham dan menguasai bahasa Inggris, sehingga menurut peneliti hal ini juga menjadi salah satu kelemahan laman Make Beliefs Comix, sebab pengaturan bahasa dalam laman tersebut tidak 
bisa diatur atau diubah menjadi bahasa Indonesia. Hal ini dikarenakan laman Make Beliefs Comix merupakan laman pembuatan komik yang berasal dari luar negeri, hingga bahasa Indonesia belum terdeteksi atau tersedia untuk menerjemahkan laman tersebut. Oleh sebab itu, dibutuhkan kemampuan berbahasa Inggris dasar tiap penggunanya, agar dapat memahami serta mengoperasikan dengan baik laman pembuatan komik digital tersebut.

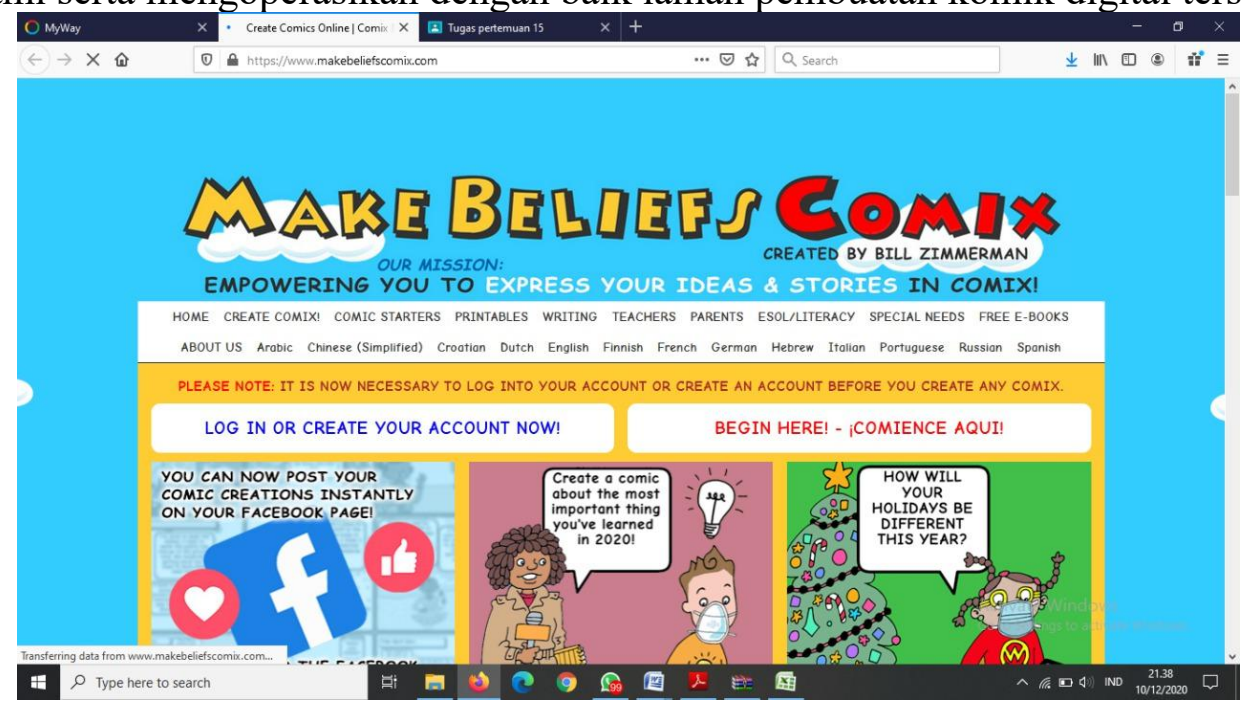

Gambar 2. Tampilan Awal Laman Make Beliefs Comix

\section{Kelebihan}

Kelebihan laman Make Beliefs Comix dalam pembuatan media pembelajaran berbasis komik digital tersebut, yakni: (1). Laman ini dapat digunakan tanpa harus mengunduh aplikasi. Salah satu kelebihan yang dimiliki oleh laman Make Beliefs Comix, yakni pengguna tidak perlu mengunduh aplikasi terlebih dahulu. Cukup mengetikkan Make Beliefs Comix di bilah pencarian, dan langsung membuka laman tersebut, maka pengguna sudah dapat mulai berkreasi membuat komik digital. Hal ini menjadi salah satu kelebihan laman Make Beliefs Comix, dengan pertimbangan bahwa ada banyak tenaga pendidik yang mungkin saja kapasitas komputernya sudah hampir penuh dan tidak lagi memungkinkan untuk mengunduh aplikasi pembuat media pembelajaran ini. Sehingga, dengan tidak perlu mengunduh aplikasi, laman ini dapat dimanfaatkan oleh tenaga pendidik dengan baik untuk menciptakan media pembelajaran yang juga baik. (2). Laman ini bisa dikreasikan oleh penggunanya yang bahkan tidak terampil dalam menggambar. Fitur-fitur yang dimiliki di laman ini semuanya sudah jadi dan sudah tersedia dalam lama tersebut. Pengguna hanya tinggal mengkreasikan tiap fitur yang ada, seperti karakter tokoh, objek-objek pendukung, latar visual, balon percakapan, dan lain sebagainya, sehingga tenaga pendidik tidak perlu lagi menggambar secara manual dalam pembuatan komik digital menggunakan laman ini. (3). Seluruh fitur yang ada dalam laman Make Beliefs Comix ini sudah jadi, sehingga penggunanya hanya tinggal mengkreasikan tiap fitur ataupun tools yang ada untuk menjadi unsur-unsur pembentuk komik yang menarik. Laman Make Beliefs Comix betul-betul memberikan kemudahan bagi tiap penggunanya, sehingga pengguna laman ini tidak perlu risau apabila tidak memiliki kemampuan menggambar sekalipun, karena telah hadir banyak fitur atau karakter yang dapat mendukung visualisasi komik digital tersebut dengan lebih mudah. Pengguna hanya perlu menambahkan karakter yang diinginkan ke dalam kanvas atau kotak, tanpa perlu khawatir dengan hasil yang tidak maksimal dikarenakan terbatasnya kemampuan menggambar. (4). Merupakan salah satu laman pembuat komik digital yang 


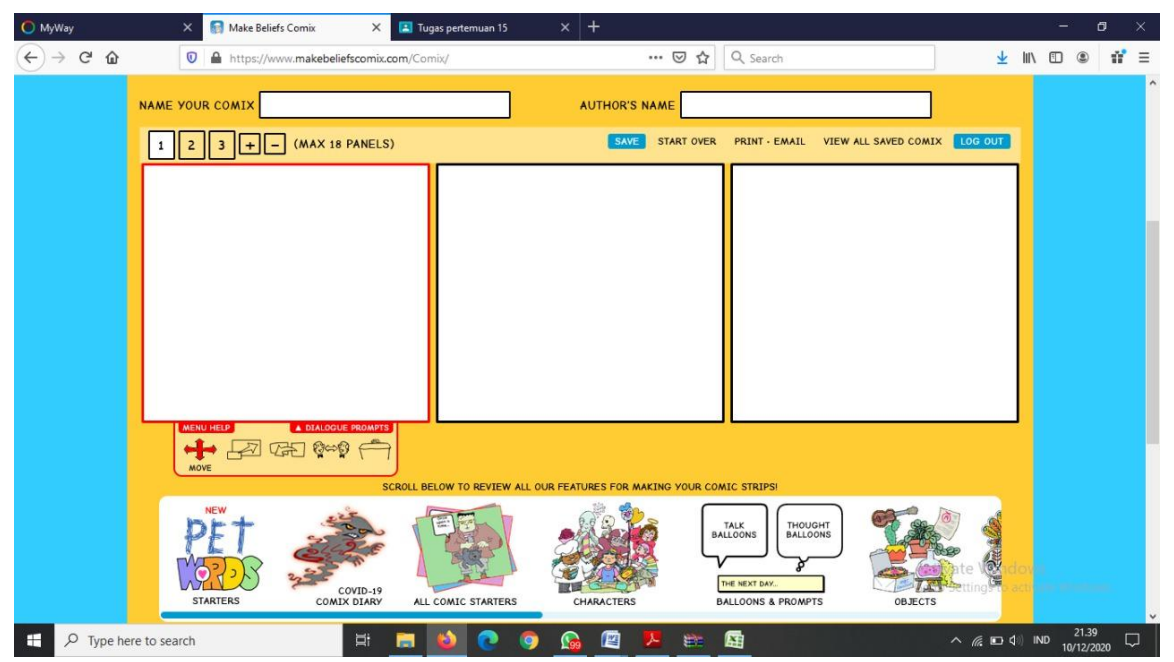

Gambar 3. Tampilan Kanvas dan Berbagai Tools dalam Laman Make Beliefs Comix mudah dioperasikan. Laman Make Beliefs Comix ini juga termasuk laman pembuatan komik digital yang mudah untuk dioperasikan, sekalipun bagi pemula. Hal ini dikarenakan bentuk tampilan utama yang sederhana, dan tidak terlalu membingungkan tampilannya. (5). Hemat biaya. Kelebihan lainnya yang dimiliki oleh laman Make Beliefs Comix ini adalah hemat biaya. Laman ini bukanlah sebuah laman pembuatan komik digital yang berbayar, seperti kebanyakan laman atau aplikasi lainnya. Fitur-fitur dan segala keunggulan dalam laman ini dapat diakses secara gratis oleh pengguna, tanpa harus membayar untuk menikmati fitur-fitur unggulannya. Pengembangan media pembelajaran berupa komik digital ini akan turut membawa tenaga pendidik pada tiap kelebihan serta kekurangan yang dimiliki oleh laman tersebut. Namun, segala kekurangan dari laman ini terbilang masih dapat diantisipasi dan diatasi oleh tenaga pendidik.

\section{Simpulan dan Saran}

Berdasarkan penelitian sederhana yang peneliti lakukan, ada sebanyak 50 dari 60 responden yang menyatakan bahwa guru bahasa Indonesia mereka belum pernah memanfaatkan media pembelajaran berupa komik digital, sehingga komik digital pada era perkembangan teknologi seperti saat ini amat menarik untuk dikembangkan lebih lanjut. Selanjutnya, sebanyak 58 dari 60 responden menyatakan media komik digital merupakan media yang amat menarik jika digunakan untuk menunjang pemahaman peserta didik dalam pembelajaran bahasa Indonesia di kelas. Laman yang bisa digunakan untuk membuat komik digital adalah laman Make Beliefs Comix. Laman ini hadir dengan berbagai keunggulan yang dapat mengatasi salah satu alasan mengapa tidak banyak tenaga pendidik yang menggunakan media pembelajaran berbasis komik digital, yakni kemampuan menggambar tenaga pendidik yang terbatas. Laman ini hadir dengan fitur-fitur menarik yang membuat tenaga pendidik tidak perlu lagi menggambar karakter tokoh, objek-objek pendukung, latar visual, dan sebagainya. Tenaga pendidik dapat langsung mengkreasikan komik dengan memanfaatkan fitur tersebut. Selain itu, laman Make Beliefs Comix dapat diakses secara gratis, dan pengguna laman ini tidak perlu mengunduh aplikasi terlebih dahulu. Era kemajuan teknologi menjadi keuntungan sebab media komik digital amat cocok digunakan, dan laman Make Beliefs Comix dengan berbagai kelebihannya dibanding aplikasi pembuat komik lain hadir untuk memudahkan tenaga pendidik membuat media pembelajaran menarik berbasis komik digital. Peneliti menyarankan bagi pendidik untuk turut memerhatikan konteks mata pelajaran yang hendak diajarkan, termasuk pada mata 
pelajaran bahasa Indonesia. Hal ini akan berpengaruh terhadap optimalnya penyampaian pembelajaran menggunakan media terkait. Bagi pembaca, diharapkan penelitian ini dapat menjadi referensi untuk melakukan penelitian lanjutan, serta memperdalam lebih lanjut mengenai telaah Pustaka menggunakan sumber lainnya, untuk menambah pengetahuan terutama mengenai media pembelajaran.

\section{Daftar Rujukan}

Adriani, Salma Rahma Chrisya, dkk. (2021). Dampak Pembelajaran Jarak Jauh Pada Masa Covid-19 di SMK Muhammadiyah 1 Sukoharjo. Jurnal Pendidikan, Vol.30(1), Maret 2021, hal.53-58. DOI: https://doi.org/10.32585/jp.v30i1.1162

Djamarah, Syaiful Bahri, dan Aswan Zain. (2010). Strategi Belajar Mengajar. Jakarta: Rineka Cipta.

Hamzah, dan Nina Lamatenggo. (2011). Teknologi Komunikasi \& Informasi Pembelajaran. Jakarta.

Kadafi, Tito Tri. (2021). Integrasi Google Art and Culture dan Google Sites sebagai Media Pembelajaran Widyawisata pada Pembelajaran Penulisan Puisi. Jurnal Pendidikan, Vol.30(1), Maret 2021, hal.23-28. DOI: https://doi.org/10.32585/jp.v30i1.1100

Kadaruddin. (2016). Media Dan Multimedia Pembelajaran. Yogyakarta: Deepublish.

Kanti, Fitra Yurisma, dkk. (2018). Pengembangan Media Pembelajaran Komik Digital pada Kompetensi Dasar Sistem Pembayaran dan Alat Pembayaran untuk Siswa Kelas X IPS di MAN 1 Jember. Jurnal Pendidikan Ekonomi, Vol.12(1), hal. 135. DOI: 10.19184/jpe.v12i1.7642

Pambudi, Rio, dkk. (2019). Pengaruh Media Video Youtube Terhadap Prestasi Belajar Matematika pada Siswa Kelas X SMK Negeri 2 Sukoharjo Tahun Ajaran 2017/2018. Jurnal Pendidikan, Vol.28(2), Juli 2019, hal.176. DOI: https://doi.org/10.32585/jp.v28i2.345

Poerwandari, E. Kristi. (1998). Pendekatan Kualitatif Dalam Penelitian. Jakarta: Lembaga Pengembangan dan Pengukuran Psikologi, Fakultas Psikologi UI

Rusman. (2009). Manajemen Kurikulum. Jakarta: Raja Grafindo Persada.

- (2013). Belajar Dan Pembelajaran Berbasis Komputer. Bandung: Alfabeta.

Sadiman, Arief S., Rahardjo, Anung Haryono, dan Harjito. (2006). Media Pendidikan: Pendidikan, Pengembangan, Dan Pemanfaatannya. Jakarta: PT Raja Grafindo Persada.

Styaningsih, Harum Aris, dkk. (2016). Pengaruh Penggunaan Media Komik Digital Terhadap Minat Belajar PPKN Siswa pada Kompetensi Dasar Mendeskripsikan Kasus Pelanggaran dan Upaya Penegakan HAM. Jurnal Profesi Pendidik. Vol.3(2), November 2016, hal. 131.

Sugiyono. (2010). Metode Penelitian Pendidikan Pendekatan Kuantitatif, Kualitatif, Dan $R \& D$. Bandung: Alfabeta.

Suwarto, S. (2017). Pengembangan tes ilmu pengetahuan alam terkomputerisasi. Jurnal Penelitian dan Evaluasi Pendidikan, 21(2), 153-161.

Wardana, Andi. (2018). Pengembangan Komik Sebagai Media Pembelajaran Untuk Mengapresiasi Cerita Anak Pada Peserta Didik Kelas III SD/MI. Universitas Islam Negeri Raden Intan Lampung.

Wahyuni, Yusri. (2017). Identifikasi Gaya Belajar (Visual, Auditorial, Kinestetik) Mahasiswa Pendidikan Matematika Universitas Bung Hatta. Jurnal Penelitian dan Pembelajaran Matematika . Vol.10(2), hal.128 